\title{
Combining green LiDAR bathymetry, aerial images and telemetry data to derive mesoscale habitat characteristics for European grayling and brown trout in a Norwegian river
}

\author{
Håkon Sundt $\mathbb{B} \cdot$ Knut Alfredsen · Jon Museth $\cdot$ Torbjørn Forseth
}

Received: 1 September 2020/Revised: 2 June 2021 / Accepted: 10 June 2021/Published online: 28 June 2021

(C) The Author(s) 2021

\begin{abstract}
While many studies provide microscale relationships between fish and habitat characteristics, studies covering longer river reaches are scarce. Modern remote sensing techniques may enable new and effective ways of mapping and assessing mesoscale habitat characteristics. Using green LIDARderived bathymetry and hydraulic modelling, we tested how mesoscale depth and velocity were related to fish counts of adult European grayling (Thymallus thymallus L.) and brown trout (Salmo trutta L.) in $500 \mathrm{~m}$ river sections in three separate periods during the year. Using riverbank sinuosity from aerial images and a Froude number-based index from the hydraulic model as proxies for mesoscale spatial and hydraulic heterogeneity, we tested for temporal correlations
\end{abstract}

Ingeborg P. Helland, Michael Power, Eduardo G. Martins \& Knut Alfredsen / Perspectives on the environmental implications of sustainable hydro-power.

H. Sundt $(\bowtie) \cdot$ K. Alfredsen

Department of Civil and Environmental Engineering, Faculty of Engineering, Norwegian University of Science and Technology - NTNU, 7491 Trondheim, Norway

e-mail: hakon.sundt@ntnu.no

J. Museth

Lillehammer Department, Norwegian Institute for Nature Research - NINA, 2624 Lillehammer, Norway

T. Forseth

Department of Aquatic Biodiversity, Norwegian Institute for Nature Research - NINA, 7485 Trondheim, Norway with river section fish counts of adult European grayling and brown trout. Results showed that mesoscale mean depth and velocity were correlated to period fish counts of adult European grayling. Using mixed model analysis we found that riverbank sinuosity and the Froude number-based index were significantly correlated with river section occurrence of adult European grayling during spawning. The results can be used to assess how flow-induced changes and channel adjustments at the mesoscale level can influence access to and use of relevant habitats in rivers occupied by European grayling and brown trout.

Keywords Spatial variation · Hydraulic modelling . Fish observation - Seasonal preferences - Mixedmodel analysis $\cdot$ Remote sensing

\section{Introduction}

River regulation can affect relevant habitats for aquatic biota through factors like fragmentation, channelization, and flow modification (Warren et al., 2015; Van Leeuwen et al., 2018; Hellström et al., 2019). Dams, weirs, embankments, and seasonal flow alteration can influence both habitat accessibility and availability (Hall et al., 2011). As habitat requirements in many cases are seasonal or life stage dependent 
(e.g., for salmonid fish), mitigation efforts in regulated rivers should, if possible, be based on ecological and physical elements across spatial and temporal scales.

The combined use of ecological and physical data have been at the heart of flow mitigation efforts in regulated rivers for decades (Richter et al., 1997; Bovee et al., 1998). However, to propose relevant mitigation and conservation efforts in rivers one must conclude with a certain level of confidence on how the physical environment influences the ecological status of local key species. Although some studies have observed significant connections between physical instream characteristics and ecological elements (Maddock et al., 2013), Petts et al. (2006) argued for an increased integration of hydraulics and ecology in conservation and mitigation management settings. Hardy (1998) addressed the need to develop a range of model tools, in close collaboration between biologist, engineers and resource managers.

While physical instream habitat models have been used for decades, they have occasionally been criticized for simplifying biotic-abiotic relationships (Railsback, 2016; see also comments by Beecher (2017) and Stalnaker et al. (2017)). One criticism focuses on the spatial and temporal scales used in habitat assessments (Heggenes et al., 1999). While fish may relate to depth and velocity at the local level (Greenberg et al., 1996; Höjesjö et al., 2007), this localized focus may ignore factors such as migration and interaction, which may be more apparent at larger spatial scales (Armstrong et al., 2003).

In environmental design studies of flow alteration in regulated rivers, hydraulic models are often used to describe and assess physical instream characteristics across spatial and temporal scales (Bustos et al., 2017). However, the hydraulic results depend on the quality of the bathymetric input. Modern techniques of terrain mapping such as remote sensing by green LIDAR can replace more traditional methods (e.g., GPS, sonar). LIDARs ("light detection and ranging" or "laser imaging, detection, and ranging") use concentrated light in different wavelengths to map a surface. The green prefix is related to the "green" wavelength $(500-565 \mathrm{~nm})$ which can penetrate water surfaces. Compared to standard bathymetric datasets, the use of green LIDAR can enhance the spatial resolution by several orders of magnitude and provide extensive datasets across large parts of river systems (Mandlburger et al., 2015). Combined with high-resolution aerial images, LIDAR data might provide highly relevant data for the analysis of physical instream characteristics (Juarez et al., 2019).

The salmonids brown trout Salmo trutta Linnaeus, 1758. and European grayling Thymallus thymallus L. coexist in many European inland rivers (Junge et al., 2014). Brown trout and European grayling differ in life history and morphology, and spawn during autumn and spring, respectively (Northcote, 1995; Jonsson \& Jonsson, 2011). Both species are rheophilic and have relatively wider range of swimming abilities compared to many other inland fish species (Ovidio et al., 2007). Although their habitat uses often overlap, European grayling are known to prefer slower flowing parts of rivers than brown trout, which has given rise to the terms "grayling zone" and "trout zone" in river classification (Huet, 1959). Hence, their differences are important to consider when assessing the consequences of altered physical conditions and flow in environmental design studies related to mitigating anthropogenic pressures in rivers. Such pressures may be hydropower development, flood protection or water removal.

Hellstrøm et al. (2019) stated that increased habitat heterogeneity could be beneficial for grayling populations and increase available territories for protection and feeding for trout. Vehanen et al. (2003) reported that adult grayling showed more flexibility in habitat requirements and preferred to stay in the vicinity of islands and reefs in a restored river section. The reason for fish choosing river sections with a higher degree of heterogeneity may be complex. Nilsson et al. (2005) hypothesized that increased variation in available physical habitat could lead to increase in land-water interactions, retention capacity of water, sediment, organic matter, and nutrients, and potentially increase the production of macroinvertebrates and fish. Boavida (2010) argues that increased physical variation in stream characteristics may increase biodiversity levels. Marsh et al. (2019) found for juvenile salmonids (Atlantic salmon Salmo salar L. and brown trout) that velocity heterogeneity was linked to habitat use and highlighted the consideration of this factor in future studies. Stream characteristics may also be also linked to the dimensionless Froude number. Wadeson (1994) and Jowett (1993) found the Froude number to be significant in distinguishing between different biotopes like pool and riffle sections (see also Hauer et al., 2011). Lamouroux \& Souchon (2002) addressed 
the use of dimensionless physical variables like the Froude number as a common denominator for habitat use in rivers located in different regions.

The mesoscale level (e.g., river sections longer than the local river width) can be relevant for conservation and mitigation management (Horne et al., 2017). Newson and Newson (2000) provide comments and overview of definitions for mesoscale units in relation to ecological research. Wegscheider et al. (2020) provides an extensive summary of mesohabitat modelling, also discussing the ecological relevance of such models. Criticism includes the lack of behavioural and biotic elements and the application for fish species more sensitive to microscale habitat changes. While a range of tools for habitat modelling exist today, they often relate to more prominent fish species like the Atlantic salmon. Also, field mesoscale mapping can be time-consuming, especially when covering large spatial and temporal ranges. With these issues in mind, there is still a need for further information on: (1) how to map and assess mesoscale habitat characteristics; and (2) determine the relevance of mesoscale habitat characteristics for European grayling and brown trout. In the present study, we addressed the above-mentioned points as described below.

(1) We mapped mesoscale habitat characteristics in two large-scale Norwegian rivers with European grayling and brown trout populations using publicly available green LIDAR data (at www. hoydedata.no) and high-resolution aerial images (at www.norgeibilder.no). We used the LIDAR data to set up a $10 \times 10 \mathrm{~cm}$ riverbed terrain grid and ran a 2D hydraulic model. From the model results we assessed depth, velocity, Froude number and wetted width in $500 \mathrm{~m}$ river sections. We then used high-resolution aerial images to calculate riverbank sinuosity and map substrate diversity in river sections.

(2) We assessed the relevance of the mesoscale habitat characteristics derived from the LIDAR data and the aerial images using telemetry data for European grayling and brown trout. First, we tested for seasonal correlations between fish occurrence and mean values of depth and velocity. Secondly, we tested for seasonal correlations between the number of fish present and spatial and hydraulic heterogeneity. We used riverbank sinuosity as a parameter for spatial variation and an interactive index with Froude number diversity, wetted width, and substrate diversity as a parameter for describing hydraulic heterogeneity.

\section{Materials and methods}

Study area

The study was conducted in the River Gudbrandsdalslågen (hereafter Lågen) and River Otta (hereafter Otta). The study area was spatially confined by the boundaries of the publicly available green LIDAR dataset which included $25 \mathrm{~km}$ of Lågen and $5 \mathrm{~km}$ of Otta. The study area was defined by three river reaches with reference to the confluence of Lågen and Otta: Lågen upstream of the confluence, Lågen downstream of the confluence and Otta (Fig. 1). Upper Lågen and Otta have average yearly flows of $32.7 \mathrm{~m} 3 \mathrm{~s}-1$ and $111 \mathrm{~m} 3 \mathrm{~s}-1$, respectively. The drainage basins are $1828 \mathrm{~km}^{2}$ and $4150 \mathrm{~km}^{2}$, respectively. During a telemetry study conducted between 2008 and 2010, observations of individual radio-tagged European grayling and brown trout were allocated to specific $500 \mathrm{~m}$ river sections. The study area was thus spatially split into river sections of $500 \mathrm{~m}$ in length corresponding to the telemetry study river sections $(n=55)$. The uppermost river section in Otta was only partly covered by the green LIDAR dataset and was excluded from the analysis.

Upper Lågen is regulated for hydropower by the Rosten power plant, which has been in operation since 2018. The Rosten plant is a run-of-the river hydropower plant (HPP) with no storage capacity. The Rosten HPP has an installed capacity of $80 \mathrm{MW}$, average yearly production of $192 \mathrm{GWh}$ and a head of $103.5 \mathrm{~m}$. The outlet of Rosten HPP is in Upper Lågen $1.5 \mathrm{~km}$ upstream of the study area, and results in negligible changes in flow due to hydropower production. The bypass section between the intake and the outlet is $5.3 \mathrm{~km}$ and runs mostly through cascade/pool river sections with natural migratory barriers for grayling and trout. Otta is regulated for hydropower by the Eidefossen plant which is a run-of-the-river hydropower system that has been in operation since 1983. The Eidefossen HPP is located $15 \mathrm{~km}$ upstream of the confluence with Lågen $(10 \mathrm{~km}$ upstream the 
Fig. 1 Map of the study area with $500 \mathrm{~m}$ fish observation river sections $(n=55)$ and three river reaches: Upper Lågen, Otta and Lower Lågen. The confluence of River Lågen and Otta is in the midsection of the study area. Black lines along the river corridor are defined by the green LIDAR dataset boundaries. Black dotted lines indicate downstream flow direction for the respective river reach

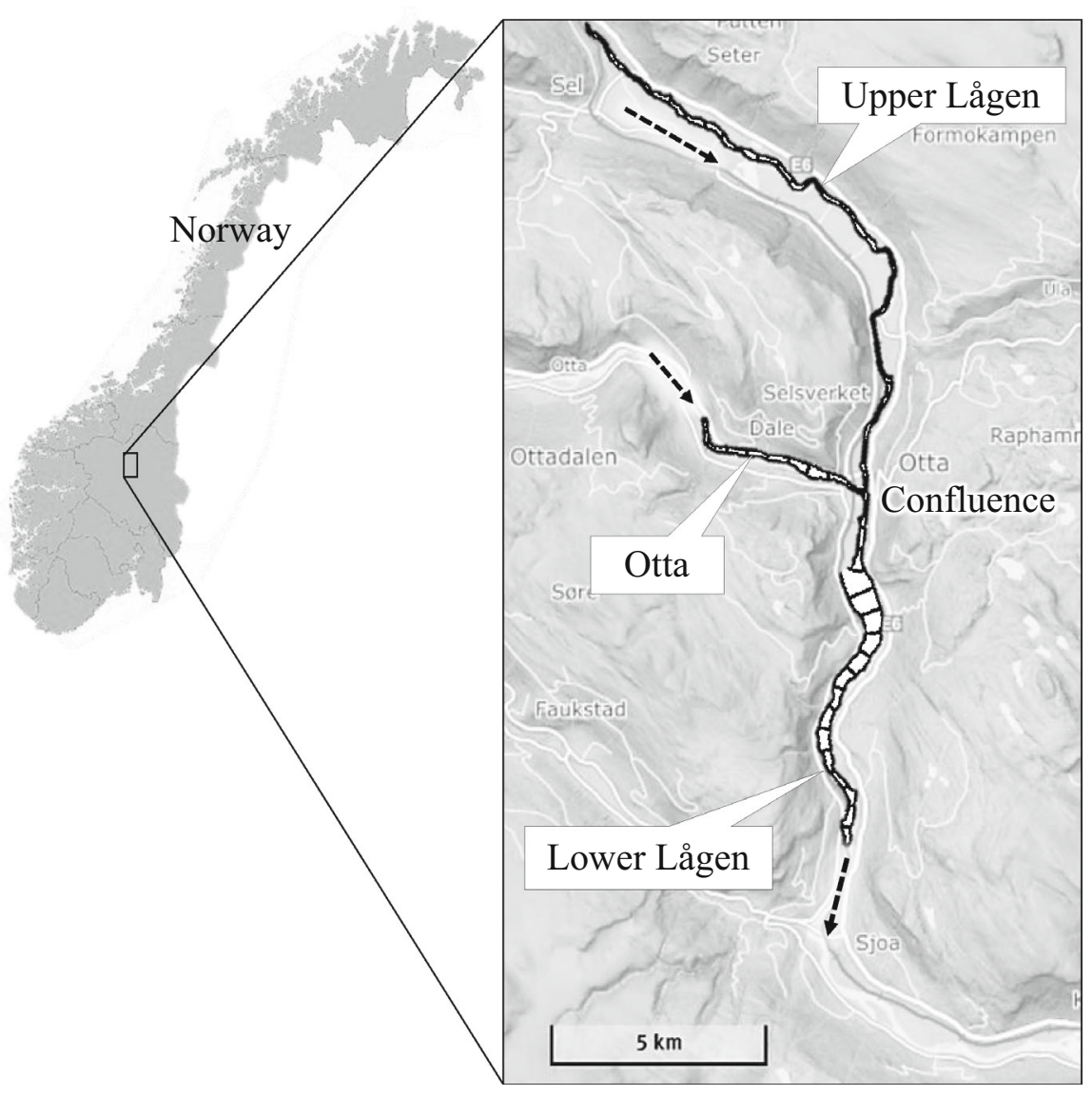

study area boundary) and has an installed capacity of 13.2 MW and average yearly production of $13 \mathrm{GWh}$. The power plant has a head of $18.9 \mathrm{~m}$.

\section{Telemetry data}

In an environmental impact assessment (EIA) addressing the hydropower development plan for Otta and Lågen, adult European Grayling (hereafter grayling) and brown trout (hereafter trout) were radio-tagged and subsequently tracked and positioned for a threeyear period from 2008 to 2010 . One of the goals of the telemetry study was to study migration patterns and identify spawning locations in relation to the hydropower development plan. All fish were caught by rod fishery, kept in keep-nets in the river until radiotagged (within three days of capture). Radio-tagging was conducted according to the Norwegian National Animal Research Authority protocols. Tags from Advanced Telemetry Systems were used (ATS, https://atstrack.com/index.html). All fish were anaesthetized, and the radio transmitters were either fixed externally right below the dorsal fin (models F1960 and F1970) or surgically inserted in the fish abdominal cavity (models F1170, F1580 or F1830). Transmitter weights varied from 2.2 to $11 \mathrm{~g}$ with an estimated life expectancy of 6 to 12 months. All transmitters made up less than $2 \%$ of the fish body weight. Full details on the radio-tagging can be found in Junge et al. (2014) and Van Leeuwen et al. (2016).

From the telemetry dataset we selected fish which repeatedly occupied the study area during all three periods. This included 25 adult grayling (mean length \pm SD: $40.2 \pm 3.9 \mathrm{~cm}$; range: $35-46 \mathrm{~cm}$ ) and 59 adult trout (mean length $\pm \mathrm{SD}: 43.7 \pm 3.9 \mathrm{~cm}$; range: $32-53 \mathrm{~cm})$.

During the telemetry study fish were tracked and allocated to predefined $500 \mathrm{~m}$ river sections once per week, and on some occasions several times per week. The period of spawning was determined by assessing the gonad status of both species. We defined three specific temporal periods for grayling and trout - their 
spawning season, winter and the rest of the yearbased on migration patterns observed throughout the telemetry study (Table 1). The rest of the year period comprised two separate periods for grayling (3rd of April through 23rd of May and 17th of June through 29th of September) and one continuous period for trout (2nd of April through 15th of September). These periods are included in the analysis for reference, but do not represent a specific life stage for either fish species.

River bathymetry and calculation of hydraulic and spatial variables

We accessed a publicly available green LIDAR and echo sounder terrain dataset through www.hoydedata. no and downloaded it as a three-dimensional point cloud within the study area boundaries. Using LAStools (LAStools, rapidlasso $\mathrm{GmbH}$, rapidlasso.com), all compressed LAZ-files were decompressed to LAS and joined in nine individual, adjacent LASD-files due to size and computational restrictions. Using ArcGIS (ESRI Inc., 2020), we built statistics for all LAS datasets and filtered the files for ground and bathymetric data. We rasterized all LASD-files into nine corresponding raster files using triangulation with natural neighbour interpolation and window size point thinning of mean point cloud z-values in $50 \times 50 \mathrm{~cm}$ cells. Each of the nine rasters were then combined into a final raster covering the entire study site.

We set up a 2D hydraulic model (HEC-RAS 5.0.7., https://www.hec.usace.army.mil/software/hec-ras/) using the combined raster as input. We built an unstructured 2D computational mesh using $10 \times 10 \mathrm{~m}$ cells. The underlying $50 \times 50 \mathrm{~cm}$ terrain was still the computational basis for all simulations of depth, velocity, and Froude number. Additional break lines were included in river sections with higher complexity of wet/dry conditions, i.e., around islands, embankments, and tributary confluences. Break lines help in the computation of areas with more complex patterns of stream flows. Flow hydrographs were set up as upstream boundary conditions, representing inflows to the River Lågen and River Otta. We used normal depth as a downstream boundary condition. We calibrated the model using the Mannings $n$ coefficient with water covered area as a target variable. The water covered area was derived from aerial images (picture resolution from $10 \mathrm{~cm}$ to $50 \mathrm{~cm}$ ) with known dates of capture and thereby known discharge. River Lågen upstream of the confluence with River Otta had aerial images acquired at discharges of $34 \mathrm{~m}^{3} \mathrm{~s}^{-1}$ and $105 \mathrm{~m}^{3} \mathrm{~s}^{-1}$, River Otta upstream of the confluence with River Lågen had aerial images at discharges of $58 \mathrm{~m}^{3} \mathrm{~s}^{-1}$ and $183 \mathrm{~m}^{3} \mathrm{~s}^{-1}$ while River Lågen downstream of the confluence with the Otta had aerial images at discharges of $92 \mathrm{~m}^{3} \mathrm{~s}^{-1}$ and $211 \mathrm{~m}^{3} \mathrm{~s}^{-1}$, all which formed the basis for the calibration. We calculated and summarized average deviation in water covered area in all 55 river sections for all calibration flows. The coefficients of determination $\left(R^{2}\right)$ for the correlation between simulated and observed water covered areas in river sections were $0.99,0.93$ and 0.99 for Upper Lågen, Otta and Lower Lågen, respectively. Based on the range of flows occurring during the telemetry registrations, we set a total flow range to use for the simulations. We then simulated flows at regular intervals between the minimum and maximum flows. The resulting distributions of hydraulic variables were exported in $10 \times 10 \mathrm{~m}$ cells for each river section and river reach occurring flow.

In River Lågen, grayling have been observed using backwater eddies during the period of spawning. To test and quantify this observation, we hypothesized that backwater eddies are more likely to occur in river sections with higher levels of spatial and hydraulic heterogeneity (as described in Fig. 2). We used riverbank sinuosity as a predictor variable to represent the spatial heterogeneity. Sinuosity was calculated in ArcGIS using a polyline approach where actual

Table 1 Defined temporal periods for all years included in the telemetry study (2008-2010) for grayling and trout

\begin{tabular}{|c|c|c|c|c|c|}
\hline \multirow[t]{2}{*}{ Temporal periods } & \multicolumn{2}{|l|}{ Spawning } & \multicolumn{2}{|l|}{ Winter } & \multirow[t]{2}{*}{ Rest of the year } \\
\hline & Start date & End date & Start date & End date & \\
\hline Grayling & 24th of May & 16th of June & 30th of September & 2nd of April & All other dates \\
\hline Trout & 16th of September & 30th of October & 31 st of October & 1st of April & \\
\hline
\end{tabular}


riverbank length was divided by the lengths of straight lines in the same river section. The straight lines were adjusted slightly for river bends to avoid overrepresentation of sinuosity in some river sections. As a proxy for hydraulic heterogeneity we defined an interactive predictor index, $F_{\text {index }}$, as the product of input variables relative width, Froude diversity and substrate diversity for each river section (Eqs. 1 and 2). Relative width is the average wetted width of the river section divided by the total average wetted width in all 55 river sections during the season. Relative width represents the flow dependent areal input variable in $F_{\text {index. Froude diversity is the zonal }}$ heterogeneity level (range 1-5) of the dimensionless Froude number within each river section and represents the flow dependent hydraulic input variable in $F_{\text {index }}($ Eq. 3). The Froude number was extracted from the hydraulic model in nodes. The Froude number represents the ratio of inertial forces to gravitational forces. Subcritical flows $(\mathrm{Fr}<1)$ indicate lower velocities and an area dominated by gravitational forces, while supercritical flows $(\mathrm{Fr}>1)$ indicate higher velocities and inertial forces domination. Froude diversity was extracted from the hydraulic model in intervals of 0.1 , and by summing the number of distinct intervals with more than $10 \%$ of the wetted area present in each river section (see Fig. 3 for an example). Level 1 implies that one dominant Froude number interval zone was present in the river section. Level 5 (i.e., the maximum observed across all river sections) implies that five available Froude number interval zones were present. Substrate diversity represents flow independent local hydromorphological conditions and was classified based on visual observation of river section bed substrate in highresolution aerial images, using a scale ranging from 1 (low diversity/single substrate size) to 6 (high diversity/large range of substrate sizes). We hypothesised that substrate diversity contributed to the hydraulic complexity within a river section, thus affecting the hydraulic heterogeneity. Table 2 gives an overview over averages and ranges for variables $F_{\text {index }}$, relative width, Froude diversity and substrate diversity.

$F_{\text {index }}=\mathrm{RW} * \mathrm{Fr}_{\mathrm{div}} * S_{\mathrm{div}}$

where: $\quad F_{\text {index }}=$ hydraulic heterogeneity index, $\mathrm{RW}=$ relative width, $\mathrm{Fr}_{\text {div }}=$ Froude diversity, $S_{\text {div }}=$ substrate diversity

$\mathrm{RW}=W_{\mathrm{rs}} / W_{\text {all }}$

where, $\mathrm{RW}=$ relative width, $W_{\mathrm{rs}}=$ average wetted

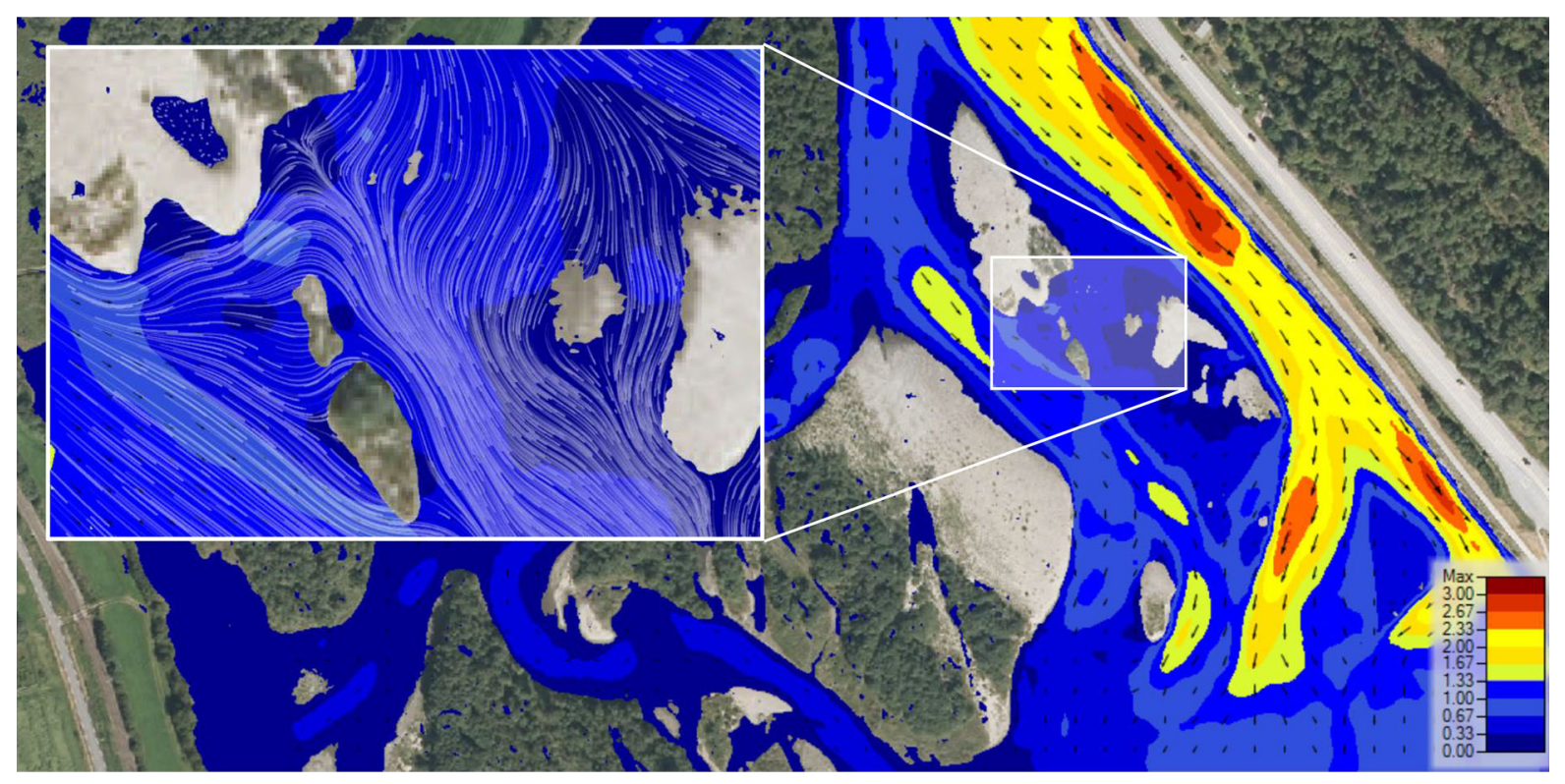

Fig. 2 Velocity zones and vectors $\left(\mathrm{m} \mathrm{s}^{-1}\right)$ and hydraulic heterogeneity in river section 36 on $200 \mathrm{~m}^{3} \mathrm{~s}^{-1}$. White framed picture in upper left corner shows velocity tracking in an area with high riverbank sinuosity. The colour scale shows simulated velocity in $\mathrm{m} \mathrm{s}^{-1}$. Background picture: copyright Statkart, Geovekst 


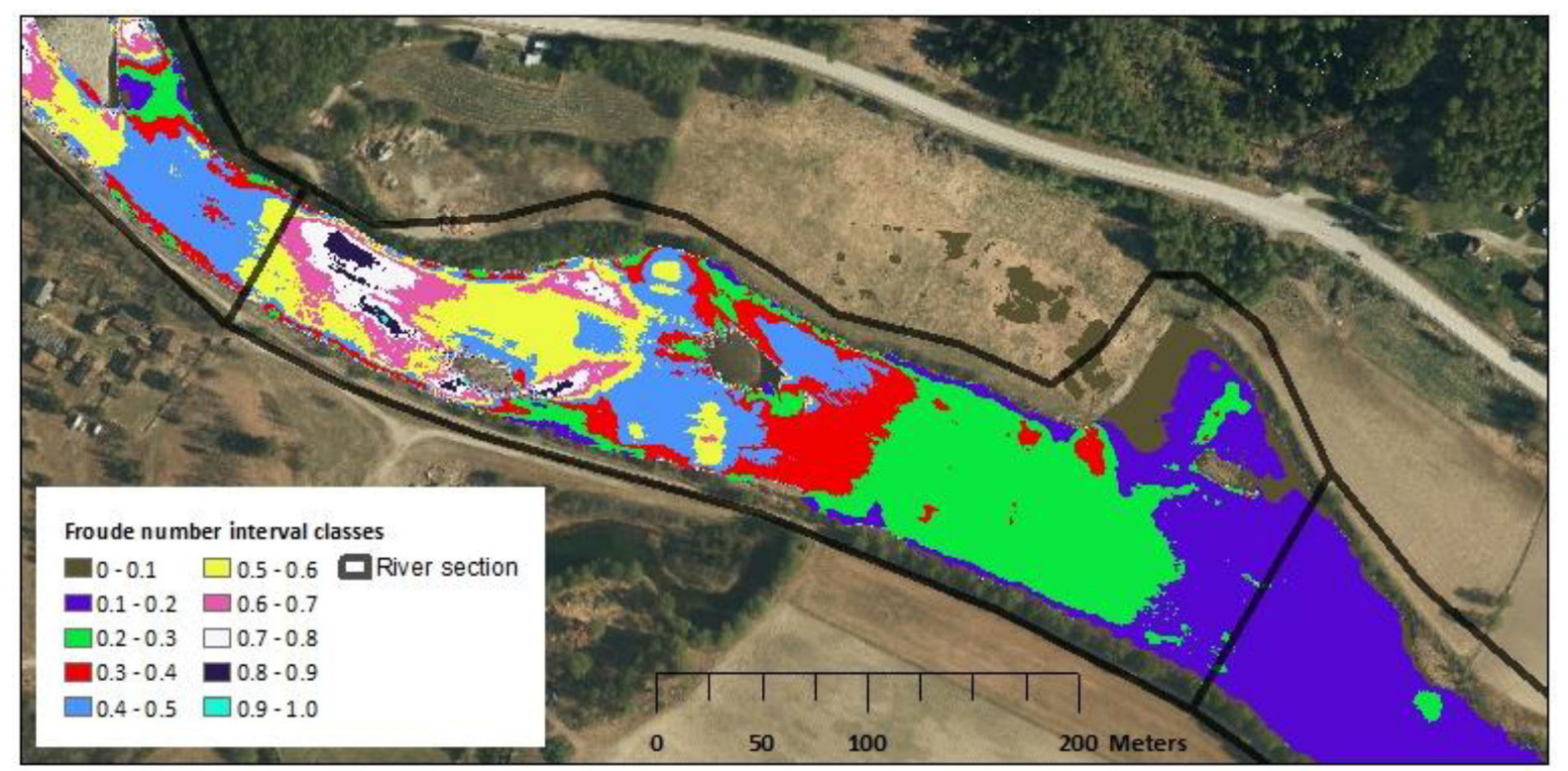

Fig. 3 Froude number interval classes in river section 6 on $100 \mathrm{~m}^{3} \mathrm{~s}^{-1}$. Froude diversity was calculated by summing all Froude number interval class zones with more than $10 \%$ of the total wetted area within the river section. Flow direction is towards right. Background picture: copyright Statkart, Geovekst

Table 2 Variable average, minimum and maximum for $F_{\text {index }}$, relative width, Froude diversity and substrate diversity

\begin{tabular}{|c|c|c|c|c|c|c|}
\hline \multirow[t]{2}{*}{ Variable } & \multicolumn{3}{|l|}{ Grayling } & \multicolumn{3}{|l|}{ Brown trout } \\
\hline & Average $\pm \mathrm{SD}$ & Min & Max & Average \pm SD & Min & Max \\
\hline$F_{\text {index }}$ & $6.28 \pm 8.51$ & 0.70 & 65.86 & $6.51 \pm 8.70$ & 0.57 & 67.99 \\
\hline Relative width, RW & $1.00 \pm 0.86$ & 0.10 & 5.04 & $1.00 \pm 0.83$ & 0.10 & 4.09 \\
\hline Froude diversity, $\mathrm{Fr}_{\mathrm{div}}$ & $2.30 \pm 1.04$ & 1.00 & 5.00 & $2.37 \pm 1.20$ & 1.00 & 5.00 \\
\hline Substrate diversity, $S_{\mathrm{div}}$ & $2.78 \pm 1.49$ & 1.00 & 6.00 & $2.78 \pm 1.49$ & 1.00 & 6.00 \\
\hline
\end{tabular}

Variable statistics are calculated from each single fish observation across all three temporal periods and for all years included in the study. As each single fish observation has its specific flow and subsequent variable value in the dataset, the statistics may differ for grayling and brown trout

width of the river section, $W_{\text {all }}=$ total average wetted width in all 55 river sections during the season

$\mathrm{Fr}=\frac{\bar{v}}{\sqrt{g H_{\mathrm{D}}}}$

where $F r=$ Froude number, $\bar{v}=$ Average velocity, $g=$ gravitational acceleration, $H_{\mathrm{D}}=$ hydraulic depth

Data analysis — depth, velocity and fish occurrence levels in river sections

To explore relationships between mean depth and velocity in the mesoscale river sections and fish observations we defined three levels of fish occurrence: (1) more than 10 repeat visits of fish during the temporal period (high occurrence), (2) between 1 and 10 visits during the temporal period (low occurrence), and (3) no visits during the temporal period (no occurrence). We included repeat visits on separate dates of the same fish individual in the analysis. The maximum recurrence was $5 \%$ in all datasets. One single fish individual tracked and registered in a river section on a specific date equalled one fish count (i.e., a single river section visit). A summary of the statistics for individual fish occurrences and river section visits are given in Table 3 .

We repeated the tests for each of the three defined temporal periods for grayling and trout: spawning, 
winter and the rest of the year. Based on observations during the telemetry study, we expected to find that fish concentrated in specific river sections, dependent on the temporal period, and that these river sections could be separated based on the mean depth and velocity. We sorted the individual river sections within the study area into the three fish occurrence levels. As the study area had three specific reaches, we accessed hydraulic model results using mean depth and velocity in each river section for an average temporal period flow for the given river reach. A Kruskal-Wallis test was used to assess the differences in mean depth and velocity among the fish occurrence levels, a suitable test for comparing two or more samples when the sample size differs, and normality cannot be assumed.

Data analysis: spatial and hydraulic heterogeneity and fish counts in river sections

We used a Generalized Linear Mixed Model (GLMM) approach to explore the relationship between the total temporal period fish counts (i.e., total number of visits) per river section and the predictor variables sinuosity and $F_{\text {index }}$ (Table 4$)$. Models were established for grayling and trout for each of the three temporal periods. To control for and assess the variation between river sections and river reaches $(n=3)$ in the study area, variables river section and reach were entered as crossed random effects with random intercepts. Due to the non-normal probability distribution of the response variable within each season, we used Poisson and negative binomial probability distributions for our models. For these distributions, a logarithmic model setup was used, and the final models were then transformed back to obtain actual intercept and slope values. All models were compared to a baseline null model (intercept only, no predictor), given in Eq. 4. Random effects are given in parenthesis. The predictor variable model setup is given in Eq. 5. Equation 6 shows the final model setup after transformation.

$\log ($ Fish count $) \sim 1+($ river reach $)+($ river section $)$ $+\varepsilon$

$\log ($ Fish count $) \sim$ predictor $+($ river reach $)$ $+($ river section $)+\varepsilon$

Fish count $\sim \exp ($ predictor $+($ river reach $)$

$$
+(\text { river section })+\varepsilon)
$$

Model coefficients (intercept and slope) were reported by log-transformation for Poisson and negative binomial distributions. For Poisson and negative binomial distributions, the fixed effect model coefficients are slope rates rather than linear slope values. The slope rates thus represent a percentage change in fish count per unit of the predictor. Slope rate values above 1 indicate an increase in fish count per unit increase in the predictor, while slope rate values below 1 indicate a decrease in fish count per unit increase in the predictor. To run and test the models we used $\mathrm{R}(\mathrm{R}$ Core Team, 2020) and glmmTMB (Brooks et al.,

Table 3 Number of repeat visits on separate dates in river sections by individual fish for three temporal periods

\begin{tabular}{|c|c|c|c|c|c|c|}
\hline & \multicolumn{3}{|l|}{ Grayling } & \multicolumn{3}{|c|}{ Brown trout } \\
\hline & Spawning & Winter & Rest of year & Spawning & Winter & Rest of year \\
\hline No. of individuals in the dataset & 25 & 25 & 25 & 59 & 59 & 59 \\
\hline No. of total visits in all river sections & 63 & 256 & 464 & 447 & 469 & 1196 \\
\hline \multicolumn{7}{|l|}{ Repeat visits by individual fish } \\
\hline Median & 3 & 10 & 21 & 7 & 8 & 21 \\
\hline Maximum & 3 & 13 & 23 & 9 & 9 & 30 \\
\hline Maximum recurrence* & $5 \%$ & $5 \%$ & $5 \%$ & $2 \%$ & $2 \%$ & $3 \%$ \\
\hline \multicolumn{7}{|l|}{ Single river section visits** } \\
\hline Median & 6 & 20 & 18 & 21 & 27 & 44 \\
\hline Maximum & 19 & 34 & 83 & 63 & 79 & 202 \\
\hline
\end{tabular}

*Maximum recurrence $=$ Maximum repeat visits by individual fish / Total number of visits in dataset

**Corresponds to response variable fish count 
Table 4 Variables and elements in the Generalized Linear Mixed Models used to test relationships between fish count and hydraulic variables

\begin{tabular}{|c|c|c|}
\hline Variable & Model element & Description \\
\hline Fish count & Response (integer) & $\begin{array}{l}\text { Total number of fish visits registered in each river section in each period. One fish count } \\
\text { equals one single visit to the river section on a specific date. Repeat visits on separate } \\
\text { dates by the same individual were included. See Table } 3 \text { for more detail on fish } \\
\text { recurrence }\end{array}$ \\
\hline $\begin{array}{l}\text { River } \\
\text { section }\end{array}$ & $\begin{array}{l}\text { "Subject" } \\
+ \\
\text { Random effect / Control }\end{array}$ & $\begin{array}{l}\text { Individual river section of } 500 \mathrm{~m} \text { length. In the study area there are a total of } 55 \text { river } \\
\text { sections: } 28 \text { in upper Lågen, } 18 \text { in lower Lågen and } 9 \text { in Otta }\end{array}$ \\
\hline River reach & Random effect / Control & The analysed area has three reaches: upper Lågen, lower Lågen and Otta. \\
\hline Sinuosity & Predictor (continuous) & $\begin{array}{l}\text { Level of sinuosity in a river section, calculated using a polyline approach where actual } \\
\text { river edge was divided by straight edge lines in the same river section. The straight lines } \\
\text { were adjusted slightly for river bends to avoid overrepresentation of sinuosity in some } \\
\text { river sections }\end{array}$ \\
\hline$F_{\text {index }}$ & $\begin{array}{l}\text { Predictor (interactive, } \\
\text { continuous) }\end{array}$ & $\begin{array}{l}\text { River section index multiplying variables relative width, Froude diversity and substrate } \\
\text { diversity }\end{array}$ \\
\hline $\begin{array}{l}\text { Relative } \\
\text { width }\end{array}$ & $\begin{array}{l}\text { Input variable to } F_{\text {index }} \\
\text { (continuous) }\end{array}$ & $\begin{array}{l}\text { Average wetted width of a river section divided by the total average wetted width in all } 55 \\
\text { river sections during the period of study. Flow dependent }\end{array}$ \\
\hline $\begin{array}{l}\text { Froude } \\
\text { diversity }\end{array}$ & $\begin{array}{l}\text { Input variable to } F_{\text {index }} \\
\quad \text { (factor, 1-5) }\end{array}$ & $\begin{array}{l}\text { Zonal heterogeneity level }(1 \text { to } 5) \text { in Froude number within each river section. Calculated } \\
\text { by sorting Froude numbers in all nodes in a river section into specific } 0.1 \text {-intervals from } \\
0 \text { to } 0.7 \text {, and then summing the number of intervals present with more than } 10 \% \text { of the } \\
\text { wetted area in the river section. Level } 1 \text { represents only one dominant Froude number } \\
\text { interval in the river section, while level } 5 \text { represents five available Froude number zones } \\
\text { that each cover more than } 10 \% \text { of the river section wetted area. Flow dependent }\end{array}$ \\
\hline $\begin{array}{l}\text { Substrate } \\
\text { diversity }\end{array}$ & $\begin{array}{l}\text { Input variable to } F_{\text {index }} \\
\quad \text { (factor, } 1-6)\end{array}$ & $\begin{array}{l}\text { Observed diversity level ( } 1 \text { to } 6 \text { ) in river section bed substrate, obtained from high- } \\
\text { resolution aerial images. Ranged from } 1 \text { (low diversity/single substrate size) to } 6 \text { (high } \\
\text { diversity/large variation in substrate size). Flow independent }\end{array}$ \\
\hline
\end{tabular}

2017). For each season and fish species we compared model performances using the Akaike's Information Criterion (AIC) as the general summary statistic. Model improvement was indicated by a lowering of the AIC value compared to the null model.

\section{Results}

Depth, velocity and fish occurrence levels in river sections

\section{European grayling}

For grayling during spawning, high occurrence river sections had lower mean depth than low- or no occurrence river sections (Fig. 4). Mean depths were significantly different between fish occurrence classes none and low, and none and high. Mean velocity was significantly lower in river sections with higher occurrence. During winter mean depth in low occurrence river sections were significantly larger than the depths at both high and no occurrence river sections. Mean velocity was significantly different among all three levels of occurrence, with the highest velocity in the no occurrence river sections. For the rest of the year period, there were no significant differences between the levels for mean depth, while mean velocity in high occurrence river sections was significantly lower than in low- and no occurrence river sections.

\section{Brown trout}

Brown trout occurrence levels were generally less related to mean depth and velocity compared to European grayling (Fig. 4 Boxplots showing depth and velocity distributions for the three fish occurrence levels for European grayling. The horizontal lines display the compared levels along with the KruskalWallis test $p$-value. Level "high" is for river sections with more than 10 repeat visits of fish during the 


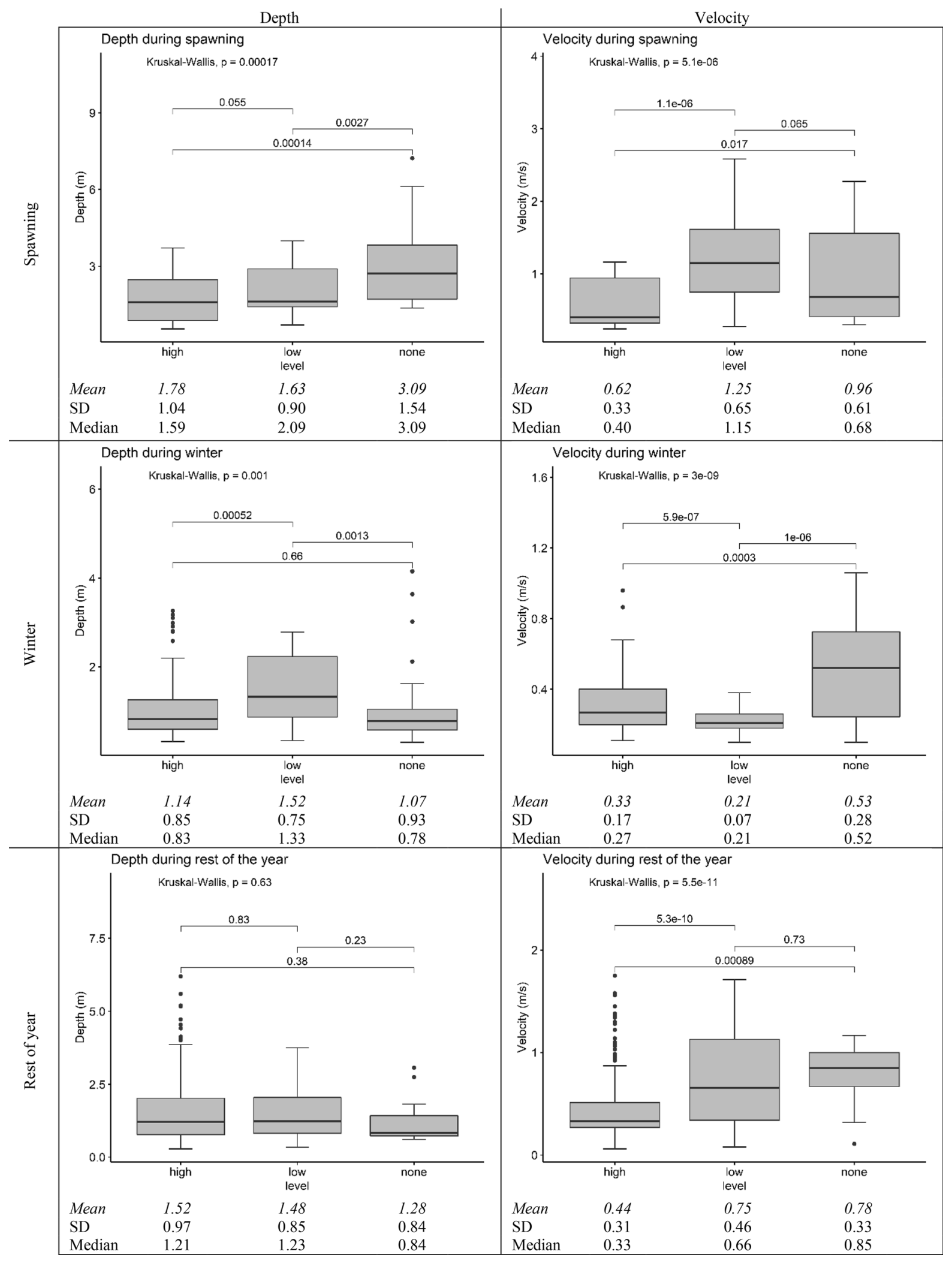


4Fig. 4 Boxplots showing depth and velocity distributions for the three fish occurrence levels for European grayling. The horizontal lines display the compared levels along with the Kruskal-Wallis test $p$-value. Level "high" is for river sections with more than 10 repeat visits of fish during the temporal period, level "low" for river sections with between 1 and 10 visits during the temporal period and "none" for river sections with no visits. Median values are shown as a black line inside each box. Outliers are shown as black dots outside of the error bars. Mean values, standard deviation and median values are given below each boxplot

temporal period, level "low" for river sections with between 1 and 10 visits during the temporal period and "none" for river sections with no visits. Median values are shown as a black line inside each box. Outliers are shown as black dots outside of the error bars. Mean values, standard deviation and median values are given below each boxplot Fig. 5). During spawning, mean depth in high occurrence river sections was significantly smaller than in low occurrence river sections, but not different from no occurrence river sections. Mean velocity in no occurrence river sections were significantly higher than in low and high occurrence river sections. During winter depth differences among the occurrence levels were small and insignificant, whereas velocity was significantly higher in no occurrence river sections than both low and high occurrence river sections. For the rest of the year period, the only significant difference was for mean depth between the high and low occurrence river sections.

Spatial and hydraulic heterogeneity and fish counts in river sections

\section{European grayling}

The best model for estimating grayling occurrence in river sections during spawning used a combination of predictors sinuosity and $F_{\text {index }}$ to calculate fish count (Eq. 7, Table 5). Using predictors sinuosity and $F_{\text {index }}$ in separate models also provided significant estimates of grayling occurrence during spawning (Eqs. 8 and 9). All three models (Table 7) improved $(p<0.001)$ on the null model (intercept only, no predictor).

The best model for grayling occurrence in river sections during the rest of the year period used single predictor sinuosity to calculate fish count (Eq. 10,
Table 6). The sinuosity model improved $(p<0.01)$ the null model. While using $F_{\text {index }}$ as a predictor for grayling occurrence during the rest of the year period provided a significant model (Equation 11, $p<0.01$ ), only the slope coefficient was significant $(p<0.01)$.

Overall model performance was best for the spawning period (AIC $<189.1$, Table 7). No significant relationships between predictors sinuosity and $F_{\text {index }}$ and grayling occurrence was found during winter. During the rest of the year overall model performance was lower than during spawning (AIC > 351.7). For both the spawning and the rest of the year periods, sinuosity was the only predictor that provided a $p<0.001$ significance level for both intercept and slope values.

\section{Brown trout}

Predictors sinuosity and $F_{\text {index }}$ explained brown trout occurrence in river sections during the rest of the year period (2nd of April through $15^{\text {th }}$ of September). No significant relationships between both predictors and fish count were found for the spawning and winter periods. For the rest of the year period both predictors improved $(p<0.01)$ the null model, but overall model performance and improvement were low $\left(\mathrm{AIC}_{\text {null }}=-\right.$ 461.9, $\triangle \mathrm{AIC}$ of -4.3 and -3.9 for sinuosity and $F_{\text {index }}$, respectively). For both predictor models, both intercept and slope coefficients were significant $(p<0.01)$. Overall model performance for brown trout in the rest of the year period was lower than for grayling in the same period.

\section{Discussion}

Our study of spatial and hydraulic heterogeneity in the rivers Lågen and Otta was enabled by access to publicly available high-density green LIDAR data and high-resolution aerial images. In a free-for-all database (www.hoydedata.no), both point clouds and digital terrain models can be downloaded. While most rivers in the database are covered by red LIDAR data and thus only returns the river surface elevation, several major rivers have been mapped using a water penetrating green LIDAR. Using the extensive LIDAR dataset to set up high-resolution bathymetric maps ( $50 \mathrm{~cm}$ cell size) we were able to obtain detailed maps of Froude number distribution and wetted width 


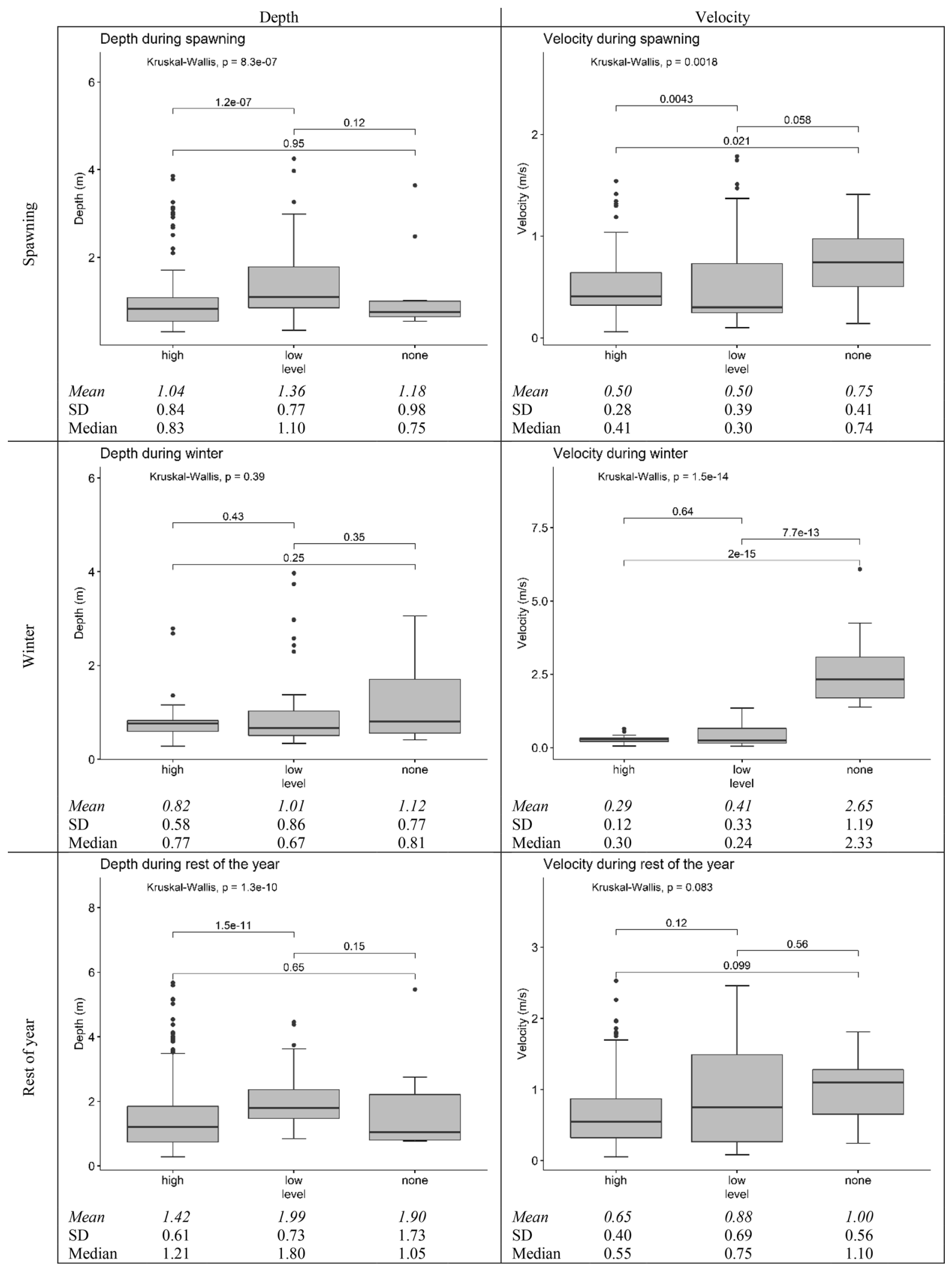


4Fig. 5 Boxplots showing depth and velocity distributions in three fish occurrence levels for brown trout. The horizontal lines display the compared levels along with the Kruskal-Wallis test p-value. Level "high" is for river sections with more than 10 repeat visits of fish during the temporal period, level "low" for river sections with between 1 and 10 visits during the temporal period and "none" for river sections with no visits. Median values are shown as a black line inside each box. Outliers are shown as black dots outside of the error bars. Mean values, standard deviation and median values are given below each boxplot

through hydraulic modelling at flows registered during the telemetry study sessions. The high-resolution aerial images were accessed at www.norgeibilder.no. Although we had institutional access to download images, all images are available for viewing at www. norgeibilder.no, including historical images. With a spatial resolution of $0.10 \mathrm{~m}$ the aerial images enabled us to map riverbank sinuosity and assess the level of substrate diversity in all river sections. An issue that might occur using LIDAR data are the temporal distance between the date for the bathymetric mapping and other interlinked studies in the same river. The combination of different datasets into an assessment of biotic-abiotic relations might require users to assess the potential changes in bathymetry between dates, due to hydromorphological changes because of floods, ice break-up and other forces. We argue that addressing biotic-abiotic relations on a mesoscale reduces the issue of bathymetric discrepancies, as hydromorphology is more likely to be stable at the mesoscale level, than at the microscale level.

Each fish observation was confined to the nearest $500 \mathrm{~m}$ river section. In our study, we defined these sections to be on the mesoscale, based on a longerthan-river-width-principle. While average river width across all seasons and flows were $109 \pm 97 \mathrm{~m}$, some sections had an average width of more than $500 \mathrm{~m}$ (maximum width was $648 \mathrm{~m}$ ). Although we were not able to test the sensitivity of river section length on the model variables and results, we found significant correlations between habitat characteristics and fish occurrence on the scale chosen in this study.

To account for the mesoscale hydraulic heterogeneity in our study area, we combined Froude number, wetted width and substrate diversity in the $F_{\text {index }}$. While other abiotic and spatial factors might be relevant, we assessed the specific use of wetted width,
Froude number and substrate diversity as variables describing the hydraulic heterogeneity. The Froude number incorporates both local depth, velocity and gravitational acceleration, accounting for a mix of hydraulically relevant variables. Wetted width adds a spatial component to address river section size (actual and relative) and substrate diversity that might account for local hydromorphological conditions and access to hydraulic shelters/refuges. In future studies an on-site mapping may be helpful in reducing the influence of subjectivity when assessing substrate diversity. As both Froude number and wetted width are dependent on flow, these factors will be influenced by altered flow regimes. The $F_{\text {index }}$ can be used to assess different flow regimes and how they will influence the hydraulic heterogeneity and consequently the response on local fish occurrences (more specifically adult European grayling). To assess mesoscale spatial heterogeneity, we hypothesized that this variation could be described by riverbank sinuosity. Higher levels of sinuosity were observed in areas with more islands and higher longitudinal/latitudinal riverbank variation. These parameters can be assessed on an aggregated level in GIS operations, provided access to relevant highresolution aerial images or maps.

Testing for correlations between fish occurrence and mean values of depth and velocity, we found that grayling preferred relatively shallow and slow-flowing river sections during the spawning season. River sections with higher mean depths and velocity were avoided during spawning. The result accords with previous observations (Mouton et al., 2008) and preference studies of grayling spawning habitats (Nykänen \& Huusko, 2002; Vehanen et al., 2003). Grayling during non-spawning period, i.e., winter and summer/autumn, were more likely to occupy slower flowing river sections. The results are comparable to velocity preferences found by Nykänen et al. (2004). For trout, we found fewer overall differences between fish occurrence levels in the three periods than for grayling. Trout were generally found in river sections with the lowest available mean depths in all periods. Results for mean depths points to values slightly higher than those reported by Armstrong et al. (2003) for spawning habitats and Cunjak and Power (1986) for winter habitats. Trout were more likely to occupy slower flowing river sections during spawning and winter, in line with observations reported by Cunjak and Power (1986) and Heggenes et al. (1993). 
Testing for seasonal correlation between the amount of fish present and spatial and hydraulic heterogeneity using a mixed model approach, we found that predictor variables sinuosity and $F_{\text {index }}$ were significantly correlated to the presence of European grayling during spawning. Slope values were positive for both predictor variables with sinuosity providing the largest slope value. Combining the two predictor variables in an interactive model provided the best model performance, when compared to the null model, but reduced overall model element significance. While no correlation was found between both sinuosity and $F_{\text {index }}$ and grayling presence during winter, we found that both variables improved the null model for grayling during the rest of the year period (3rd of April through 23rd of May and 17th of June through 29th of September). We emphasise that model results for the fragmented rest of the year period for grayling were included only as a reference and do not represent a specific life stage. For brown trout, we found that the variables sinuosity and $F_{\text {index }}$ were positively related to fish presence during the rest of the year period (2nd of April through 15th of September), but overall model performance was low and the model was thus excluded from the results.

In our study area, grayling have historically been observed to use river sections with a presence of backwater eddies during spawning. While we did not map backwater eddies (or note fish observations in these), we assumed that backwater eddies were more likely to occur in areas with higher levels of spatial and hydraulic heterogeneity. Our results in 500 river sections provide a significant and quantified relationship between grayling occurrence and spatial and hydraulic heterogeneity during spawning. We also found that heterogeneity may influence grayling and trout in the rest of the year period. Even though heterogeneity is mentioned as a relevant factor in determining the habitat use of salmonids in river systems (Nilsson et al., 2005; Boavida, 2010; Hellstrøm et al., 2019), there is still a lack of studies quantifying this.

Greenberg et al. (1996) addressed the issue of transferability of preferences between rivers by concluding that while microscale depth and velocity preferences of European grayling and brown trout may be similar within regions, no universal habitat suitability relations exist. This was based on factors such as habitat availability, fish density, and food and biotic interactions, which may vary between rivers. Armstrong et al. (2003) took a more general view by stating that, while models often are adapted to single rivers or streams, models incorporating local abiotic features and catchment-scale variables might be more suitable for conservation and management purposes and more applicable across river systems. Our findings indicate that mesoscale depth and velocity preferences may be adequate to address fish occurrence of European grayling during spawning, while the results are less clear for grayling during winter and the rest of the year. We would argue that addressing depth and velocity at a mesoscale level might provide adequate input to conservation and mitigation efforts in rivers and future studies on biotic-abiotic relationships,

Table 5 Models for estimating European grayling occurrence during spawning (24th of May through 16th of June) using predictors sinuosity and $F_{\text {index }}$ interactively and separately

\begin{tabular}{lllr}
\hline Season & Predictor & Log-transformed model & \\
\hline Spawning & Sinuosity $* F_{\text {index }}$ & Fish count $=\exp \left(-2.29+1.61 *\right.$ sinuosity $+0.15 * F_{\text {index }}-0.03 *$ sinuosity $\left.: F_{\text {index }}\right)$ & Eq. 7 \\
& $F_{\text {index }}$ & Fish count $=\exp \left(-0.92+0.10 * F_{\text {index }}\right)$ & Eq. 8 \\
& Sinuosity & Fish count $=\exp (-1.47+0.89 *$ sinuosity $)$ & Eq. 9 \\
\hline
\end{tabular}

Table 6 Models for estimating European grayling occurrence during the rest of the year period (3rd of April through 23rd of May and 17 th of June through 29 th of September) using predictors sinuosity and $F_{\text {index }}$ separately

\begin{tabular}{llll}
\hline Season & Predictor & Log-transformed model & \\
\hline Rest of the year & Sinuosity & Fish count $=\exp (1.56+0.40 *$ sinuosity $)$ & Eq. 10 \\
& $F_{\text {index }}$ & Fish count $=\exp \left(1.83+0.03 * F_{\text {index }}\right)$ & Eq. 11 \\
\hline
\end{tabular}


Table 7 Log-linear mixed model coefficients for European grayling during spawning and the rest of the year period

\begin{tabular}{|c|c|c|c|c|c|c|c|}
\hline Season & Distribution & Predictors & Intercept & Slope element & Slope & AIC & $\Delta \mathrm{AIC}$ \\
\hline \multirow[t]{4}{*}{ Spawning } & Poisson & Null $(\sim 1)$ & 0.65 & & & 189.1 & \\
\hline & Poisson & Sinuosity & $0.23 * * *$ & & $2.43 * * *$ & 174.0 & $-15.1 * * *$ \\
\hline & Poisson & $\mathrm{F}_{\text {index }}$ & $0.40 *$ & & $1.10 * * *$ & 168.4 & $-20.7 * * *$ \\
\hline & Poisson & Sinuosity $* \mathrm{~F}_{\text {index }}$ & $0.06 * *$ & $\begin{array}{l}\text { Sinuosity } \\
\mathrm{F}_{\text {index }} \\
\text { Sinuosity: } \mathrm{F}_{\text {index }}\end{array}$ & $\begin{array}{l}5.00 \\
1.16 * * \\
0.99 * *\end{array}$ & 163.7 & $-25.4 * * *$ \\
\hline \multirow[t]{3}{*}{ Rest of the year } & Neg. bin. & Null $(\sim 1)$ & $7.39 * * *$ & & & 359.8 & \\
\hline & Neg. bin. & Sinuosity & $4.77 * * *$ & & $1.49 * * *$ & 351.7 & $-8.10 * *$ \\
\hline & Neg. bin. & $\mathrm{F}_{\text {index }}$ & 6.21 & & $1.03 * * *$ & 354.1 & $-5.7 * *$ \\
\hline
\end{tabular}

$* * * p<0.001, * * p<0.01, * p<0.05, ' ? p<0.1$, ' ‘ = not significant

A Poisson distribution was used for the response variable during spawning and a negative binomial distribution was used during the rest of the year period. All intercepts and slopes are exponentials of log-linear model coefficients. The null model is for the intercept only. Predictor models show intercept and slope (ratio change by predictor unit)

especially when combined with an assessment of spatial and hydraulic heterogeneity at the same level.

\section{Conclusion}

As remote sensing technology advances and becomes more accessible in terms of cost and availability, LIDAR data might enable large-scale habitat assessments across spatial scales. The availability of highresolution aerial images might also provide valuable input to habitat assessments, including mapping of substrate and spatial heterogeneity in rivers. As hydraulic heterogeneity represented by $F_{\text {index }}$ is flow dependent, it might be relevant on a short-term basis when addressing e.g., minimum flow requirements. The flow independent spatial heterogeneity factor sinuosity might be relevant in long-term assessments, e.g., flood protection measures, riverbank protection and conservational issues. While our results remain to be validated through comparative studies in other rivers, we believe our results on spatial and hydraulic heterogeneity can provide a relevant model framework for use in management processes and environmental design studies in regulated rivers.

Acknowledgments We thank Richard Hedger for his kind assistance and support on mixed modelling and R programming along with manuscript language improvement. This project was funded as part of HydroCen (Norwegian Research Centre for Hydropower Technology, https://www.ntnu.edu/hydrocen). We thank all relevant partners and colleagues in HydroCen for providing input and discussions on topics related to the analysis. We thank the people at NINA that did the work on the telemetry study prior to this study. We thank Atle Harby at SINTEF Energi for providing critical comments at an early stage.

Funding Open access funding provided by NTNU Norwegian University of Science and Technology (incl St. Olavs Hospital Trondheim University Hospital).

Open Access This article is licensed under a Creative Commons Attribution 4.0 International License, which permits use, sharing, adaptation, distribution and reproduction in any medium or format, as long as you give appropriate credit to the original author(s) and the source, provide a link to the Creative Commons licence, and indicate if changes were made. The images or other third party material in this article are included in the article's Creative Commons licence, unless indicated otherwise in a credit line to the material. If material is not included in the article's Creative Commons licence and your intended use is not permitted by statutory regulation or exceeds the permitted use, you will need to obtain permission directly from the copyright holder. To view a copy of this licence, visit http://creativecommons.org/licenses/by/4.0/.

\section{References}

Armstrong, J. D., P. S. Kemp, G. J. A. Kennedy, M. Ladle \& N. J. Milner, 2003. Habitat requirements of Atlantic salmon and brown trout in rivers and streams. Fisheries Research 62: 143-170.

Beecher, H. A., 2017. Comment 1: Why it is time to put PHABSIM out to pasture. Fisheries 42: 508-510.

Boavida, I., 2010. Fish habitat availability simulations using different morphological variables. Limnetica 30: 393-404. 
Bovee, K. D., J. M. Bartholow, C. B. Stalnaker, J. Taylor \& J. Henriksen, 1998. Stream habitat analysis using the instream flow incremental methodology. U. S. Geological Survey, Biological Resources Division Information and Technology Report, U. S. Geological Survey.

Brooks, M. E., K. Kristensen, K. J. van Benthem, A. Magnusson, C. W. Berg, A. Nielsen, H. J. Skaug, M. Machler \& B. M. Bolker, 2017. glmmTMB balances speed and flexibility among packages for zero-inflated generalized linear mixed modeling. R Journal 9: 378-400.

Bustos, A. A., R. D. Hedger, H. P. Fjeldstad, K. Alfredsen, H. Sundt \& D. N. Barton, 2017. Modeling the effects of alternative mitigation measures on Atlantic salmon production in a regulated river. Water Resources and Economics 17: 32-41.

Cunjak, R. A. \& G. Power, 1986. Winter habitat utilization by stream resident brook trout (Salvelinus-Fontinalis) and brown trout (Salmo-Trutta). Canadian Journal of Fisheries and Aquatic Sciences 43: 1970-1981.

Esri Inc., 2020. ArcGIS Desktop (Version 10.8). Esri Inc. https://www.esri.com/en-us/home

Greenberg, L., P. Svendsen \& A. Harby, 1996. Availability of microhabitats and their use by brown trout (Salmo trutta) and grayling (Thymallus thymallus) in the River Vojman, Sweden. Regulated Rivers-Research \& Management 12: 287-303.

Hall, C. J., A. Jordaan \& M. G. Frisk, 2011. The historic influence of dams on diadromous fish habitat with a focus on river herring and hydrologic longitudinal connectivity. Landscape Ecology 26: 95-107.

Hauer, C., G. Unfer, M. Tritthart, E. Formann \& H. Habersack, 2011. Variability of mesohabitat characteristics in rifflepool reaches: testing an integrative evaluation concept (fgc) for mem-application. River Research and Applications 27: 403-430.

Hardy, T. B., 1998. The future of habitat modeling and instream flow assessment techniques. Regulated Rivers-Research \& Management 14: 405-420.

Heggenes, J., O. M. W. Krog, O. R. Lindas, J. G. Dokk \& T. Bremnes, 1993. Homeostatic behavioral-responses in a changing environment - brown trout (salmo-trutta) become nocturnal during winter. Journal of Animal Ecology 62: 295-308.

Heggenes, J., J. L. Bagliniere \& R. A. Cunjak, 1999. Spatial niche variability for young Atlantic salmon (Salmo salar) and brown trout (S-trutta) in heterogeneous streams. Ecology of Freshwater Fish 8: 1-21.

Hellström, G., D. Palm, T. Brodin, P. Rivinoja \& M. Carlstein, 2019. Effects of boulder addition on European grayling (Thymallus thymallus) in a channelized river in Sweden. Journal of Freshwater Ecology 34: 559-573.

Horne, A. C., E. L. O’Donnell, M. Acreman, M. E. McClain, N. LeRoy Poff, J. Angus Webb, M. J. Stewardson, N. R. Bond, B. Richter, A. H. Arthington, R. E. Tharme, D. E. Garrick, K. A. Daniell, J. C. Conallin, G. A. Thomas \& B. T. Hart, 2017. Chapter 27 - Moving forward: The implementation challenge for environmental water management. Water for the Environment. Academic Press.

Huet, M., 1959. Profiles and biology of western European streams as related to fish management. Transactions of the American Fisheries Society 88: 155-163.
Höjesjö, J., F. Okland, L. F. Sundstrom, J. Pettersson \& J. I. Johnsson, 2007. Movement and home range in relation to dominance; a telemetry study on brown trout Salmo trutta. Journal of Fish Biology 70: 257-268.

Jonsson, B. \& N. Jonsson, 2011. Habitats as Template for Life Histories. Ecology of Atlantic Salmon and Brown Trout: Habitat as a template for life histories. Fish \& Fisheries Series, vol. 33. Springer, Netherlands

Jowett, I. G., 1993. A method for objectively identifying pool, run, and riffle habitats from physical measurements. New Zealand Journal of Marine and Freshwater Research 27: 241-248.

Juarez, A., A. Adeva-Bustos, K. Alfredsen \& B. O. Donnum, 2019. Performance of a two-dimensional hydraulic model for the evaluation of stranding areas and characterization of rapid fluctuations in hydropeaking rivers. Water 11: 201.

Junge, C., J. Museth, K. Hindar, M. Kraabol \& L. A. Vollestad, 2014. Assessing the consequences of habitat fragmentation for two migratory salmonid fishes. Aquatic ConservationMarine and Freshwater Ecosystems 24: 297-311.

Lamouroux, N. \& Y. Souchon, 2002. Simple predictions of instream habitat model outputs for fish habitat guilds in large streams. Freshwater Biology 47: 1531-1542.

Maddock, I., A. Harby, P. Kemp \& P. J. Wood, 2013. Ecohydraulics: An Integrated Approach. Wiley-Blackwell, New York.

Mandlburger, G., C. Hauer, M. Wieser \& N. Pfeifer, 2015. Topo-bathymetric lidar for monitoring river morphodynamics and instream habitats - a case study at the pielach river. Remote Sensing 7: 6160.

Marsh, J. E., R. B. Lauridsen, S. D. Gregory, W. R. C. Beaumont, L. J. Scott, P. Kratina \& J. I. Jones, 2019. Above parr: Lowland river habitat characteristics associated with higher juvenile Atlantic salmon (Salmo salar) and brown trout (S. trutta) densities. Ecology of Freshwater Fish 00: $1-15$.

Mouton, A. M., M. Schneider, A. Peter, G. Holzer, R. Muller, P. L. M. Goethals \& N. De Pauw, 2008. Optimisation of a fuzzy physical habitat model for spawning European grayling (Thymallus thymallus L.) in the Aare river (Thun, Switzerland). Ecological Modelling 215: 122-132.

Newson, M. D. \& C. L. Newson, 2000. Geomorphology, ecology and river channel habitat: mesoscale approaches to basin-scale challenges. Progress in Physical Geography: Earth and Environment 24: 195-217.

Nilsson, C., F. Lepori, B. Malmqvist, E. Tornlund, N. Hjerdt, J. M. Helfield, D. Palm, J. Ostergren, R. Jansson, E. Brannas \& H. Lundqvist, 2005. Forecasting environmental responses to restoration of rivers used as log floatways: An interdisciplinary challenge. Ecosystems 8: 779-800.

Northcote, T. G., 1995. Comparative biology and management of arctic and european grayling (salmonidae, thymallus). Reviews in Fish Biology and Fisheries 5: 141-194.

Nykänen, M., A. Huusko \& M. Lahti, 2004. Movements and habitat preferences of adult grayling (Thymallus thymallus L.) from late winter to summer in a boreal river. Archiv Fur Hydrobiologie 161: 417-432.

Nykänen, M. \& A. Huusko, 2002. Suitability criteria for spawning habitat of riverine European grayling. Journal of Fish Biology 60: 1351-1354. 
Ovidio, M., H. Capra \& J. C. Philippart, 2007. Field protocol for assessing small obstacles to migrating brown trout Salmo trutta, and European grayling Thymallus thymallus: a contribution to the management of free movement in rivers. Fisheries Management and Ecology 14: 41-50.

Petts, G., Y. Morales \& J. Sadler, 2006. Linking hydrology and biology to assess the water needs of river ecosystems. Hydrological Processes 20: 2247-2251.

R Core Team, 2020. R: A language and environment for statistical computing. R Foundation for Statistical Computing, Vienna, Austria. http://www.R-project.org/.

Railsback, S. F., 2016. Why it is time to Put PHABSIM out to pasture. Fisheries 41: 720-725.

Richter, B., J. Baumgartner, R. Wigington \& D. Braun, 1997. How much water does a river need? Freshwater Biology 37: 231-249.

Stalnaker, C. B., I. Chisholm \& A. Paul, 2017. Don't throw out the baby (PHABSIM) with the bathwater: bringing scientific credibility to use of hydraulic habitat models, specifically PHABSIM. Fisheries 42: 510-516.

Van Leeuwen, C. H. A., J. Museth, O. T. Sandlund, T. Qvenild \& L. A. Vøllestad, 2016. Mismatch between fishway operation and timing of fish movements: a risk for cascading effects in partial migration systems. Ecology and Evolution 6: 2414-2425.
Van Leeuwen, C. H. A., K. Dalen, J. Museth, C. Junge \& L. A. Vøllestad, 2018. Habitat fragmentation has interactive effects on the population genetic diversity and individual behaviour of a freshwater salmonid fish. River Research and Applications 34: 60-68.

Vehanen, T., A. Huusko, T. Yrjänä, M. Lahti \& A. Mäki-Petäys, 2003. Habitat preference by grayling (Thymallus thymal$l u s)$ in an artificially modified, hydropeaking riverbed: a contribution to understand the effectiveness of habitat enhancement measures. Journal of Applied Ichthyology 19: 15-20.

Wadeson, R. A., 1994. A geomorphological approach to the identification and classification of instream flow environments. Southern African Journal of Aquatic Sciences 20: 38-61.

Warren, M., M. J. Dunbar \& C. Smith, 2015. River flow as a determinant of salmonid distribution and abundance: a review. Environmental Biology of Fishes 98: 1695-1717.

Wegscheider, B., T. Linnansaari \& R. A. Curry, 2020. Mesohabitat modelling in fish ecology: a global synthesis. Fish and Fisheries 21: 927-939.

Publisher's Note Springer Nature remains neutral with regard to jurisdictional claims in published maps and institutional affiliations. 